\title{
Anticholinesterase activities from aqueous extract of different plant parts of Erica manipuliflora
}

\author{
Çiğdem KUŞ ${ }^{* 1}$, Mehmet Emin DURU', Meltem TAŞ${ }^{1}$, Selçuk KÜÇÜKAYDIN ${ }^{1}$ \\ ${ }^{1}$ Muğla Sıtkı Koçman University, Faculty of Sciences, Department of Chemistry, Muğla/Turkey
}

Received: 30 April 2017 - Revised: 03 June 2017 - Accepted: 27 June 2017

\begin{abstract}
Erica species are generally spread along the coasts of Turkey. There are five Erica species in these regions, namely; E. arborea, E. manipuliflora, E, bocquetii, E. sicula subsp. Libanotica and E. spiculifolia salisb. Among these species, E. manipuliflora is commonly found in Muğla and southwest part of Turkey. Erica species are called as "funda", "püren" or "tree heath" locally in Turkey and contain biologically active compounds such as flavonoids, coumarins and triterpenoids. Since ancient times, these species have been used as herbal tea and folk medicine by local people in Turkey. In folk medicine, they are used for diuretic, antiseptic and anti-inflammatory purposes. Inhibition of acetylcholinesterase (AChE) and butyrylcholinesterase (BChE) is useful for the treatment of Alzheimer's disease. In this study anticholinesterase activity of aqueous extracts of leaves, flowers and aerial parts of E. manipuliflora have been investigated spectrophotometrically. The aerial parts extract of $E$. manipuliflora among the extracts $(70.10 \%)$ showed the best inhibitory activity against AChE enzyme at 200 $\mu \mathrm{g} / \mathrm{mL}$ concentrations. The extracts of leaves and flowers showed $44.42 \%, 49.91 \%$ inhibitions against acetylcholinesterase enzyme at $200 \mu \mathrm{g} / \mathrm{mL}$ concentrations respectively. The flowers extract of E. manipuliflora (80.41\%) exhibited the best BChE inhibitory activity at $200 \mu \mathrm{g} / \mathrm{mL}$ concentrations. At the same concentration, the galantamine showed $82.23 \%$ inhibitory activity. Leaves and aerial parts extracts showed $15,75 \%, 31.62 \%$ inhibitory activity against BChE respectively. Hence, aerial parts of E. manipuliflora may be useful as a moderate anticholinesterase agent, and flowers of E. manipuliflora may be useful as the butyrylcholinesterase agent.
\end{abstract}

Keywords: Erica, Erica manipuliflora, acetylcholinesterase, butyrylcholinesterase, enzyme inhibition

\section{INTRODUCTION}

Genus Erica belongs to Ericaceae family, which comprise 4250 species spread across 124 genera, and is a large family in the world [1]. Erica is represented by five species in Turkey and one of them is endemic. They are distributed in the coastal sides and South West Anatolia. These are E. arborea L., E. manipuliflora Salisb., E. sicula Guss. subsp. libanotica, E. spiculifolia salisb and E.bocquetii [2]. These species are commonly known as "funda", "püren" or "tree heath," in Turkey [3]. The therapeutic functions of Ericaceae family members generally are attributed to a variety of polyphenolic derivatives [4, 5]. Species of Erica have been reported to possess various medicinal activities such as, antiulcer, cytotoxic [6], hyperlipidemia [7], antiseptic, diuretic, antiviral, astringent, sedative, wound-healing [8], anti-inflammatory and antinociceptive $[9,10]$. These species contain many active components such as monoterpenes and condensed tannins, phenylpropanoid glycoside and flavonoids [11]. Moreover, heather honey is obtained from Erica species. Heather (Ericaceae) is an important melliferous plant for

${ }^{*}$ Corresponding Author E-mail: cigdem_kus@hotmail.com 
honey bees [12]. In the literature, heather honey which possessed high antioxidant activity and high phenolic composition make them valuable food items for human health [13].

Alzheimer's disease is characterized with impaired memory and behavior. Acetylcholinesterase (AChE) inhibitor has been used as a drug for the treatment of Alzheimer's disease because acetylcholine level is enhanced in the brain by using AChE inhibitors [14]. Recently, the searching for new AChE inhibitors from plant sources is of great interest among scientists [15]. AChE usually presents in the brain and BChE in the peripheral tissues [16]. Extracts of several medicinal plants have been reported to be effective in the inhibition of $\mathrm{BChE}$ and AChE [17]. Several plants from Ericaceae family have shown a very strong inhibitory activity against $\mathrm{AChE}$ and $\mathrm{BChE}[18]$.

In this study, it was aimed to investigate the inhibitory activities on acetylcholinesterase and butyrylcholinesterase enzymes by using infusions obtained from three different parts of the Erica manipuliflora plant (leaf, flower and aerial parts) commonly growing in Muğla.

\section{MATERIAL and METHODS}

\subsection{Plant Material}

Erica manipuliflora were randomly selected and collected at the flowering period in October of 2016 from Muğla-Ula in Turkey. After collection, plant material was stored in a dry place, completely protected from sunlight. After drying, leaves, flowers and aerial parts of the plant were manually separated and stored at $-4^{\circ} \mathrm{C}$ until extraction.

\subsection{Preparation of Infusions}

Plant materials $(20 \mathrm{~g})$ were added to $50 \mathrm{~mL}$ of ultra-distilled water (at the initial temperature of $85^{\circ} \mathrm{C}$ ) for $15 \mathrm{~min}$, with stirring. Infusions were filtered and their volume was made up to $50 \mathrm{~mL}$. Aqueous infusions were finally transferred to flat bottom flasks. Water were evaporated by freeze-dryer and extracts were stored at $-4^{\circ} \mathrm{C}$.

\subsection{Determination of anticholinesterase activity}

The AChE and BChE inhibitory activities were measured by slight modifications of the spectrophotometric method [19]. All conditions were identical to those described in the earlier publication [20]. Galantamine was used as a reference compound. The results are given as the percentage of inhibition concentration.

\section{RESULTS and DISCUSSIONS}

In this study, aqueous extractions from three different parts (leaves, flower, aerial parts) of Erica manipuliflora were obtained by infusion. The obtained extracts have been investigated for their inhibitory activities on acetylcholinesterase and butyrylcholinesterase enzymes according to the method given above. Galantamine was used as reference standard. The results are given in Table 1 and Table 2. 
Table 1. Acetylcholinesterase enzyme inhibitory activities of the infusions of E. manipuliflora leaves, flowers, aerial parts

\begin{tabular}{lcccc}
\hline & \multicolumn{4}{c}{$\%$ Inhibition } \\
Aqueous Extracts & $25 \mu \mathrm{g} / \mathrm{mL}$ & $50 \mu \mathrm{g} / \mathrm{mL}$ & $100 \mu \mathrm{g} / \mathrm{mL}$ & $200 \mu \mathrm{g} / \mathrm{mL}$ \\
\hline Infusion of Erica leaves (ELT) & $13.48 \pm 1.85$ & $26.78 \pm 1.78$ & $35.50 \pm 1.32$ & $44.42 \pm 1.95$ \\
Infusion of Erica aerial parts (EAT) & $35.36 \pm 1.20$ & $51.22 \pm 1.64$ & $64.84 \pm 1.52$ & $70.10 \pm 1.79$ \\
Infusion of Erica flowers (EFT) & $19.36 \pm 1.75$ & $27.28 \pm 1.47$ & $37.51 \pm 1.88$ & $49.91 \pm 1.14$ \\
Standard (Galantamine) & $75,99 \pm 0.05$ & $78,08 \pm 0.47$ & $78,76 \pm 0.08$ & $80,41 \pm 0.05$ \\
\hline
\end{tabular}

Table 2. Butyrylcholinesterase enzyme inhibitory activities of the infusions of E. manipuliflora leaves, flowers, aerial parts

\%Inhibition

\begin{tabular}{lcccc} 
Aqueous Extracts & $25 \mu \mathrm{g} / \mathrm{mL}$ & $50 \mu \mathrm{g} / \mathrm{mL}$ & $100 \mu \mathrm{g} / \mathrm{mL}$ & $200 \mu \mathrm{g} / \mathrm{mL}$ \\
\hline Infusion of Erica leaves (ELT) & $3,46 \pm 3,49$ & $11,83 \pm 1,84$ & $12,92 \pm 5,17$ & $15,75 \pm 2,93$ \\
Infusion of Erica aerial parts (EAT) & $8,82 \pm 2,25$ & $16,46 \pm 2,20$ & $21,22 \pm 0.41$ & $31,62 \pm 0,90$ \\
Infusion of Erica flowers (EFT) & $43,62 \pm 9,37$ & $57,64 \pm 1,73$ & $69,10 \pm 0,35$ & $80,41 \pm 0,98$ \\
Standard (Galantamine) & $64,99 \pm 0.05$ & $73,96 \pm 0.08$ & $79,27 \pm 0.17$ & $82,23 \pm 0.15$ \\
\hline
\end{tabular}

\section{DISCUSSION and CONCLUSION}

The infusion of aerial parts of E. manipuliflora at $200 \mu \mathrm{g} / \mathrm{mL}$ concentration has shown the highest inhibitory activity $(70.10 \%)$ against acetylcholinesterase enzyme, while the infusion of flowers has exhibited maximum inhibitory activity $(80,41 \%)$ against butyrylcholinesterase enzyme. All tests were compared to galantamine is used as a reference compound. According to this result, the infusion of aerial parts of E. manipuliflora has exhibited a moderate inhibitory activity against AChE. On the other hand, infusion of flowers has shown almost the same inhibition value with the reference compound (galantamin) against the BChE enzyme. Thus, we can say that the infusion of E. manipuliflora flowers has the best level inhibitory activity against the butyrylcholinesterase enzyme.

\section{Conflict of Interests}

Authors declare that there is no conflict of interests.

\section{REFERENCES}

[1] Christenhusz, M. J., \& Byng, J. W. (2016). The number of known plants species in the world and its annual increase. Phytotaxa,261(3), 201-217.

[2] Güvenç, A., \& Kendir, G. (2007). The leaf anatomy of some Erica taxa native to Turkey. Fabad Journal of Pharmaceutical Sciences, 32, 121-125.

[3] Baytop, T. (1999). Türkiye'de Bitkiler ile Tedavi Geçmişte ve Bugün. 2nd ed. İstanbul: Nobel Tip Kitabevleri.

[4] Marquez-Garcia, B., Fernandez, M.A., \& Cordoba, F. (2009). Phenolics composition in Erica sp. differentially exposed to metal pollution in the Iberian Southwestern pyritic belt. Bioresource technology, 100, 446-451.

[5] Guendouze-Bouchefa, N., Madani, K., Chibane, M., Boulekbache-Makhlouf, L., Hauchard, D., Kiendrebeogo, M., Stevigny, C., Okusa, P.N., \& Duez, P. (2015). Phenolic compounds, antioxidant and antibacterial activities of three Ericaceae from Algeria. Industrial Crops and Products, 70, 459-466. 
[6] Reyes, R. M., Martin-Cordero, C., Gonzalez, M. J., Toro Sainz, M. V. \& Alarcón de la Lastra, C. (1996). Antiulcer Activity in Rats by Plavonoids of Erica andevalensis Cabezudo-Rivera. Phytotherapy Research, 10, 300-303.

[7] Harnafi, H., Bouanani, N.H., Aziz, M., Caid, H.S., Ghalim, N., \& Amrani, S. (2007). The hypolpidaemic activity of aqueous Erica multiflora $L$. flowers extract in Triton WR-1339 induced hyperlipidaemic rats: a comparison with fenofibrate. Journal of Ethnopharmacology, 190(1), 156-160.

[8] Rios, J.L., Recio, M.C., \& Villar, A. (1987). Antimicrobial activity of selected plants employed in the Spanish Mediterranean area. The Journal of Ethnopharmacology, 21, $139-152$.

[9] Küpeli Akkol, E., Yeşilada, E., \& Güvenç, A. (2008). Valuation of anti-inflammatory and antinociceptive activities of Erica species native to Turkey. Journal of Ethnopharmacology, 116, 251-257.

[10] Sadki, C., Hacht, B., Souliman, A., \& Atmani, F. (2010). Acute diuretic activity of aqueous Erica multiflora flowers and Cynodon dactylon rhizomes extracts in rats. Journal of Ethnopharmacology, 128, 352-356.

[11] Nazemiyeh, H., Bahadori, F., Delazar, A., Ay, M., Topçu, G., Nahar, L., Majinda, R.R.T. \& Sarker, S. D. (2008). Antioxidant phenolic compounds from the leaves of Erica Arborea (Ericaceae). Natural Product Research, 22(16), 1385-1392.

[12] Enkegaard, A., Kryger, P., \& Boelt, B. (2016). Determinants of nectar production in heather. Journal of Apicultural Research, 55(1), 100-106.

[13] Baltrušaitytè, V., Venskutonis, P. R., \& Čeksteryte, V. (2007). Radical scavenging activity of different floral origin honey and beebread phenolic extracts. Food Chemistry, 101, 502514.

[14] Işık, A.T. (2012). Her Yönüyle Alzheimer Hastalığ1- (Geriatrik Sendromlar Dizisi 5), Türkiye, Som Kitap.

[15] Mukherjeea, P. K., Kumarb, V., Malb, M., \& Houghtona, P.P. (2007). Acetylcholinesterase inhibitors from plants. Phytomedicine, 14, 289-300.

[16] Orhan, I., Sener, B., Choudhary, M.I., \& Khalid, A. (2004). Acetylcholinesterase and butyrylcholinesterase inhibitory activity of some Turkish medicinal plants. Journal of Ethnopharmacology, 91, 57-60.

[17] Ingkaninan, K., Temkitthawon, P., Chuenchom, K., Yuyaem, T., \& Thongnoi, W. (2003). Screening for acetylcholinesterase inhibitory activity in plants used in Thai traditional rejuvenating and neurotonic remedies. Journal of Ethnopharmacology, 89, 261-264.

[18] Dias, P. Falé, P. L., Martins, A., \& Rauter, A. P. (2015). Digestibility and Bioavailability of the Active Components of Erica australis L. Aqueous Extracts and Their Therapeutic Potential as Acetylcholinesterase Inhibitors. Evidence-Based Complementary and Alternative Medicine.

[19] Ellman, G.L., Courtney, K.D., Andres, V., \& Featherston, R.M. (1961). A new and rapid colorimetric determination of acetylcholinesterase activity. Biochemical Pharmacology, 7 , 88-95.

[20] Öztürk, M. (2012). Anticholinesterase and antioxidant activities of Savoury (Saturejathymbra L.) with identified major terpenes of the essential oil. Food Chemistry, $134,48-54$. 